\title{
The Relationship Between the Methods of Male Circumcision Procedures Used in the Past and the Prevalence of Viral Hepatitis
}

\author{
Erkeklerde Geçmiște Sünnet Yapılma Șekli ve Viral Hepatit Sıklı̆ı Arasındaki llișki
}

\author{
Selma TOSUN1, İsmail BALIK2, Neşe INAN3, Neşe SALTOĞLU4, Necati ÖRMECI5, Irfan ŞENCAN6, \\ Fehmi TABAK4
}

\author{
$1 / z m i r$ Bozyaka Training and Research Hospital, Clinic of Infectious Diseases, Izmir, Turkey \\ ${ }^{2}$ Ankara University Faculty of Medicine, Department of Infectious Diseases, Ankara, Turkey \\ 3/stanbul Bilim University Faculty of Medicine, Department of Microbiology, Istanbul, Turkey \\ 4/stanbul University Cerrahpaşa Faculty of Medicine, Department of Infectious Diseases, Istanbul, Turkey \\ ${ }^{5}$ Ankara University Faculty of Medicine, Department of Gastroenterology, Ankara, Turkey \\ ${ }^{6}$ Dışkapı Yıldırım Beyazı Training and Research Hospital, Clinic of Infectious Diseases, Ankara, Turkey
}

\begin{abstract}
Objective: The study was designed to evaluate the relationship between the methods of circumcision procedures used in the past and hepatitis B surface antigen (HBsAg), anti-HBs and anti-hepatitis $\mathrm{C}$ virus (HCV) positivity.

Materials and Methods: Within the scope of "Public Hepatitis Awareness Activities" executed by the Viral Hepatitis Society, volunteer participants who were admitted to primary healthcare centers across the Turkey, were screened for HBsAg, anti-HBs and anti-HCV positivity. A standard questionnaire form regarding their circumcision procedure in the past was applied via face-to-face interview method to each participant while their blood samples were collected for the analysis of hepatitis B virus and HCV positivity. Results: HBsAg, anti-HBs and anti-HCV positivity rates were $3.6 \%$, $9.9 \%$ and $0.6 \%$ respectively. HBsAg positivity was significantly higher in group of participants who have been circumcised by a traditional non-medical person than in the other group of subjects who have been circumcised by a health professional (3.3\% vs $5.3 \%, p=0.003$ ). Conclusion: Circumcision is a widespread practice based on the existing cultural and religious traditions in islamic countries like Turkey. Mass circumcision and circumcision performed by traditional nonmedical persons like barbers is still one of the important health-care problems with the risk of transmission of viral infections in Turkey. The results will help to take measures for preventing viral hepatitis transmission.
\end{abstract}

Keywords: Anti-HBs, anti-HCV, barbers, circumcision, hepatitis B surface antigen, hepatitis
ÖZ

Amaç: Bu çalışma, geçmişte sünnet yapılma şekli ve hepatit $B$ yüzey antijeni (HBsAg), anti-HBs ve anti-hepatit $\mathrm{C}$ virüsü (HCV) pozitifliği arasındaki ilişkinin incelenmesi amacı ile dizayn edilmiştir.

Gereç ve Yöntemler: Viral Hepatitle Savaşım Derneği'nce hayata geçirilen "Toplum Hepatit Farkındalık Aktiviteleri" kapsamında, tüm Türkiye genelinde sağlık ocaklarına başvuran gönüllü katılımcılar HBsAg, anti-HBs ve anti-HCV pozitifliği açısından taranmıştır. Katılımcıların hepatit B virüsü ve HCV pozitifliği analizleri için kan örneklerinin alındığı sırada, geçmişteki sünnet prosedürü ile ilgili standart anket formu yüz yüze görüşme metodu ile her katılımcı için doldurulmuştur.

Bulgular: $\mathrm{HBsAg}$, anti-HBs ve anti-HCV pozitiflik oranları sırası ile $\% 3,6, \% 9,8$ ve $\% 0,6$ olarak bulunmuştur. HBsAg pozitifliği sünneti geleneksel, sağlık personeli tarafından yapılmayan grupta sağlık personeli tarafından sünnet edilen gruba göre anlamlı olarak yüksek bulunmuştur ( $\% 3,3$ vs $\% 5,3, p=0,003)$. Gruplar arasında anti-HBs ve anti-HCV pozitifliği açısından anlamlı bir ilişki saptanmamıştır (\%0,6 vs $\% 0,8, p=0,533$ )

Sonuç: Sünnet, Türkiye gibi islam ülkelerinde, kültürel ve dini geleneklere dayanan oldukça yaygın bir uygulamadır. Türkiye'de, toplu sünnet ve geleneksel berberler gibi sağlık personeli olmayan kişilerce yapılan sünnet, viral enfeksiyonların bulaşma riski ile birlikte, hala önemli sağlık sorunlarından biridir. Sonuçlar, viral hepatit bulaşında önleyici önlemler almaya yardımcı olabilir.

Anahtar Kelimeler: Anti-HBs, anti-HCV, berber, sünnet, hepatit B yüzey antijeni, hepatit 


\section{Introduction}

Hepatitis infection is a major global public health problem with high mortality and morbidity rates due to serious complications, such as chronic hepatitis, cirrhosis and primary liver cancer (1). Almost one-third of the world population has been infected with hepatitis B virus (HBV) and about 350 million of these remain chronically infected. On the other hand, approximately $3 \%$ of the world population has been infected with hepatitis $\mathrm{C}$ virus $(\mathrm{HCV})$ and 170 million people are chronic carriers of $\mathrm{HCV}(2,3)$. Traditional practices including rituals, such as circumcision, traditional medicine and the other activities which damage the skin, e.g. tattooing or body piercing have been considered among the potential sources of blood-borne infections like $\mathrm{HCV}$ in case of contaminated instrument usage (3). It is estimated that one out of three males worldwide is circumcised (4). Circumcision is mostly performed for social and religious reasons in $99 \%$ of the male population in Turkey (5). However, controversy surrounds the procedure and its benefits and risks to health (6). The incidence and nature of various complications resulting from unsafe male circumcision along with the potential benefits has been the subject of much discussion. In this regard, the availability of healthcare, trained staff and appropriate hygiene have been documented among significant factors to decrease complications related to circumcision $(6,7,8)$.

Based on the role of population-based epidemiological studies on the estimation of the relative contribution of the various sources of infection, prioritization of preventive measures and making the most appropriate use of available resources in a particular country (9), this screening study was designed to evaluate the relationship between circumcision and hepatitis B surface antigen (HBsAg), anti-HBs and anti-HCV positivity.

\section{Materials and Methods}

Setting: This cohort study was conducted as a part of the "Public Hepatitis Awareness Activities" executed by the Viral Hepatitis Society of Turkey with the permission of the Turkish Ministry of Health. A descriptive questionnaire was used to obtain the sociodemographic features of the subjects and the method of circumcision. A detailed explanation concerning objectives and protocol of the study, application and interpretation of the blood analysis for viral hepatitis workup and questionnaire forms as well as contact details of the study coordinator was sent to the investigator (general practitioner or family physician) working at the primary healthcare centers across Turkey before the initiation of the study.

Laboratory Testing: Participants were screened in terms of $\mathrm{HBsAg}$, anti-HBs, and anti-HCV positivity. A total of 8-10 $\mathrm{ml}$ of blood was collected from each participant to analyze serum samples for investigating $\mathrm{HBsAg}$, anti-HBsAg and anti-HCV positivity by using immunochromatographic cassette test (Rapid Card Test Nanosign, Bioland, Chungbuk, Korea) and the screening method and the positive results were confirmed by enzymatic immunoassay (EIA).

Data Collection: Five thousand eight hundred eighty four male volunteers of 18-79 ages [mean age: 35.0 (standard deviation \pm 14.1 ) years] were eligible to participate in the study from all over the cities in Turkey. Prior to data collection, oral informed consent was obtained from each subject following a detailed explanation of the objectives and protocol of the study were implemented after the permission of the Turkish Ministry of Health. Five thousand eight hundred eighty four male participants completed the questionnaire prepared for investigating the relationship of the method of circumcision with $\mathrm{HBsAg}$, anti-HBs and anti-HCV positivity. A standard questionnaire form was applied via face to face interview method to each participant. The questions about the type and place details of the circumcision included in questionnaire form.

Statistical Methods: Statistical analyses were made using SPSS version 13.0 (SPSS Inc. Chicago, IL, USA). Chi-square $\left(x^{2}\right)$ test was used for the comparison of categorical data and the Mantel-Haenszel test was used for the analysis of linear relationship between ordinal variables. ANOVA and post-hoc Tukey test were used for the parametric variables. Data were expressed as mean (standard deviation), minimum-maximum and percent (\%) where appropriate; a p value of less than 0.05 was considered statistically significant.

\section{Results}

HBsAg, anti-HBs and anti-HCV positivity were identified in 213 of $5.878(3.6 \%), 231$ of $2339(9.9 \%)$ and 37 of $5.884(0.6 \%)$ participants, respectively (Table 1).

When the subjects were classified as being circumcised by health professionals or nonmedical persons, HBsAg positivity was found to be significantly higher ( $n=165 / 4987$ (3.3\%) vs. 48/897 $(5.3 \%) ; p=0.003)$ in the latter group, while there was no significant association for anti-HBs (10.0\% vs. $8.8 \%, \mathrm{p}=0.486)$ and anti-HCV $(0.6 \%$ vs. $0.8 \%, p=0.533)$ positivity between groups (Table 2 ).

Table 1. Type of the circumcision with respect to serological findings

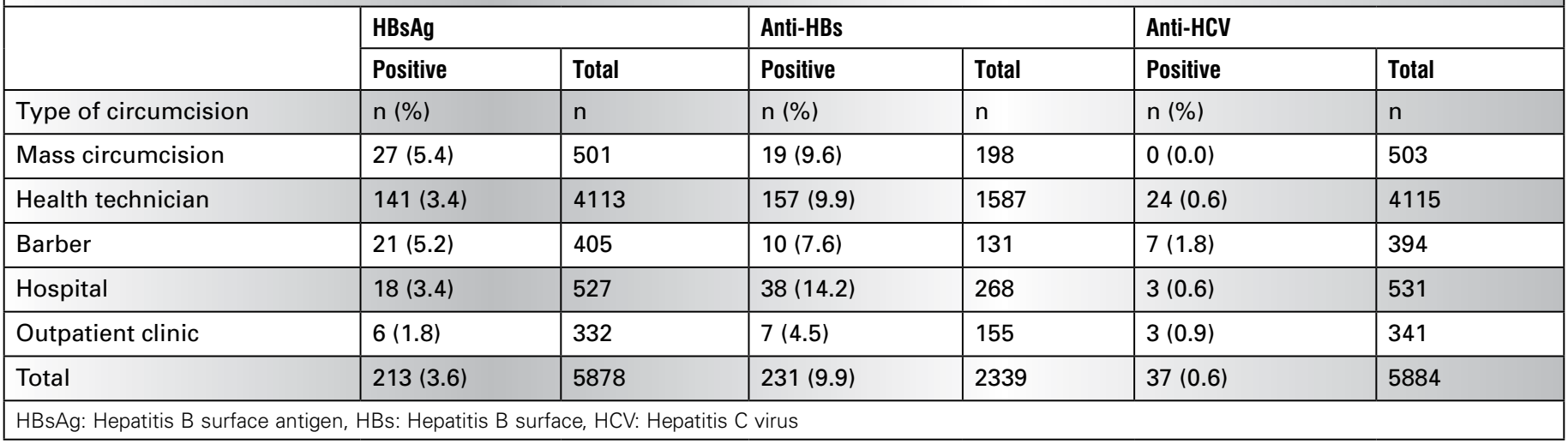




\section{Discussion}

Education and counselling programs have been suggested to inform practitioners of traditional and folk medicine (e.g. tattooing, body piercing and circumcision) as well as people using such services about the risk of hepatitis infection due to the use of non-sterile instruments or objects (1). Therefore, it seems more safe to make circumcision in the hospitals instead of other unhygienic places outside the hospitals in terms of medical complications (10). In our study, it was obvious that only a very small proportion of circumcisions were done in the hospitals $(n=531)$ in compared to the outside the hospital in Turkey. Indeed, most of the circumcisions in Turkey have been documented to be performed at home, health centers or schools. Mass circumcisions are usually done as a part of religious ceremonies sponsored by charity organizations and local administrations or political societies. Although experienced doctors, health workers or technicians were identified to perform some of these circumcisions; in rural areas, most of the circumcisions have been reported to be performed by unexperienced staff (10). Likewise, in a previous study concerning frequency of hepatitis $B$ and $C$ in rural and periurban Sindh, only $14.8 \%$ of individuals, circumcision was identified to be performed by doctors, while in the remaining it was done by barbers using unsterilized instruments (11).

On the other hand, recent epidemiological studies have shown that male circumcision has a protective effect against sexuallytransmitted diseases (12). However, usage of contaminated equipment during mass circumcision may cause transmission of blood-borne viruses such as HBV. In their study, Aweis et al. (13) investigated the prevalence hepatitis $B$ and the risk factors of HBsAg-carriage among Somali population living in Liverpool and they found that a history of circumcision in Somalia was the most significant predisposing factor.

Mass circumcision is a very common practice, especially, in cases of charity; hundreds of children are being circumcised by traditional nonmedical people. In such cases, high probability of using the same surgical equipments for more than one child increases the risk of HBV infection (14). Otkun et al. (14) reported that the overall HBsAg-seropositivity was $1.7 \%$ and, notably, mass circumcision was documented as the only independent factor according to regression analysis comparing with uncircumcised children and those circumcised singly (anti$\mathrm{HBc}$ positivity rates were $12.5 \%, 4.5 \%$ and $6.2 \%$, respectively).
Ozdemir (15) indicated that traditional nonmedical persons were responsible for $85 \%$ of the circumcision complications. The frequency of complication associated with mass circumcision was significantly higher than that related with circumcisions performed singly in operating room conditions. In our study, overall HBsAg-positivity in total population was 3.6\%. We found that mass circumcision and circumcisions performed by barbers were associated with higher rates of HBsAg-positivity $15.4 \%$ and $5.2 \%$, respectively). When the subjects were classified as being circumcised by a traditional non-medical person or a health professional, HBsAg positivity was significantly higher in the first group [5.3\% (48/897) vs 3.3\% (165/4987)] ( $p=0.003)$. There were no significant relationship between anti-HBs $(8.8 \%$ vs $10 \%, p=0.486)$ and anti-HCV positivity $(0.8 \%$ vs $0.6 \%$, $\mathrm{p}=0.533$ ).

Likewise, in a previous study about the prevalence and risk factors of hepatitis B and C virus infections in an impoverished urban community in Dhaka, Bangladesh, HBV positivity was identified in $84.1 \%$ of the patients with circumcision history. There was a significant association between circumcision with HBVseropositivity (OR 3.21, p<0.001) (16).

Medhat et al. (17) researched risk factors for HCV infection in a village in Upper Egypt. They found that circumcision is a very common procedure and was not associated per se with anti-HCV presence, however, circumcision by a nonmedical person rather than a health professional was associated with anti-HCV among young male population $(4.9 \%$ vs $0.5 \%, \mathrm{p}<0.001)$. In our study, anti-HCV prevalence was not seemed to be associated with circumcision type or person.

Although, it is an important study for population healthcare, this study has some limitations. We don't have anti-HBs results for all participants, we had limited anti-HBs tests in some regions of the country during the study period. We could not get any information about pre-circumcision HBV and HCV serology results, hepatitis infections in related to other risk factors (tattoos, scarification, injection, drug use, surgical procedures, etc.) that may contribute the hepatitis infections. We could not have any medical records of participants related with the circumcision procedure to confirm the inquiry results. In our study population, circumcision was performed at childhood period but the mean age of the participants during the study was 35 years; so adults might not remember important informations about their circumcision, which were the questions they were asked for the study.

Table 2. Comparison of hepatitis serology in circumcisions performed by health professionals (health technician, in a hospital, in a private outpatient clinic) or nonmedical persons (barber, mass circumcision)

\begin{tabular}{|c|c|c|c|c|c|c|}
\hline & \multicolumn{2}{|l|}{ HBsAga } & \multicolumn{2}{|l|}{ Anti-HBs ${ }^{b}$} & \multicolumn{2}{|l|}{ Anti-HCVc } \\
\hline & Positive & Total & Positive & Total & Positive & Total \\
\hline Circumcision by & n (\%) & $\mathrm{n}$ & $\mathrm{n}(\%)$ & $\mathrm{n}$ & n (\%) & $n$ \\
\hline Nonmedical person & $48(5.3)$ & 906 & $29(8.8)$ & 329 & $7(0.8)$ & 897 \\
\hline Total & $213(3.6)$ & 5878 & $231(9.9)$ & 2339 & $37(0.6)$ & 5884 \\
\hline
\end{tabular}




\section{Conclusion}

In conclusion, our findings, representing the first large-scale epidemiological data on circumcision and hepatitis transmission in Turkey, indicating mass circumcisions and circumcisions done by barbers that may pose a great risk for public health for their significant relationship with higher incidence of HBsAg positivity. Mass circumcision has been done for sociocultural and religious reasons for many years and it is usually done outside the health centers. For adequate infection controlling practices and prevention of infectious transmission, it is important to establish guidelines to ensure standardization of circumcision procedure and also maintain the educational collaborations of health officials with traditional non-medical circumcisers in Turkey.

Acknowledgement: This study sponsored by Viral Hepatit Society of Turkey. Viral hepatitis assay kits were donated by the pharmaceutical companies.

\section{Ethics}

Ethics Committee Approval: This trial done with permission of Basic Health Department of Ministry of Health. Informed Consent: Verbal consent was obtained from.

Peer-review: External and Internal peer-reviewed.

\section{Authorship Contributions}

Concept: Ismail Balık, Fehmi Tabak, Irfan Şencan, Neşe Saltoğlu, Design: Ismail Balık, Fehmi Tabak, Necati Örmeci, Data Collection or Processing: Selma Tosun, Fehmi Tabak, Neşe Saltoğlu, Analysis or Interpretation: Selma Tosun, Literature Search: Selma Tosun, Neşe Inan, Writing:Selma Tosun, Neşe Inan.

Conflict of Interest: No conflict of interest was declared by the authors.

Financial Disclosure: The authors declared that this study received no financial support.

Tosun S, Balık I, Inan N, Saltoğlu N, Örmeci N, Sencan I, Tabak F. The Relationship between the Methods of Male Circumcision Procedures Used in the Past and the Prevalence of Viral Hepatitis. Viral Hepatitis J 2016;22:6-9.

\section{References}

1. Lavanchy D. Chronic viral hepatitis as a public health issue in the world. Best Pract Res Clin Gastroenterol. 2008;22:991-1008.

2. Andre F. Hepatitis B epidemiology in Asia, the Middle East and Africa. Vaccine. 2000;18(Suppl 1):20-22.
3. Lavanchy D. Public health measures in the control of viral hepatitis: a World Health Organization perspective for the next millennium. J Gastroenterol Hepatol. 2002;17(Suppl):452-459.

4. Senel FM, Demirelli M, Misirlioglu F, Sezgin T. Adult male circumcision performed with plastic clamp technique in Turkey: results and long-term effects on sexual function. Urol J. 2012;9:700-705

5. Turk E, Karaca F, Edirne Y. A clinical and epidemiological study on the age of circumcision in Turkey. J Ann Eu Med. 2013;1:2730.

6. Moses S, Bailey RC, Ronald AR. Male circumcision: assessment of health benefits and risks. Sex Transm Infect. 1998;74:368373.

7. Aridogan $\mid A$, Izol $V$, IIkit M. Superficial fungal infections of the male genitalia: a review. Crit Rev Microbiol. 2011;37:237-244.

8. Dushoff J, Patocs A, Shi CF. Modeling the population-level effects of male circumcision as an HIV-preventive measure: a gendered perspective. PLoS One. 2011;6:28608.

9. Lavanchy D. Hepatitis C: public health strategies. J Hepatol. 1999;31(Suppl 1):146-151.

10. Ceylan K, Burhan K, Yilmaz Y, Can S, Kus A, Mustafa G. Severe complications of circumcision: an analysis of 48 cases. J Pediatr Urol. 2007;3:32-35.

11. Aziz S, Khanani R, Noorulain W, Rajper J. Frequency of hepatitis $\mathrm{B}$ and $\mathrm{C}$ in rural and periurban Sindh. J Pak Med Assoc. 2010;60:853-857.

12. Halioua B, Lobel B. Actual controversies about circumcision. Presse Med. 2014;43:1168-1173.

13. Aweis D, Brabin BJ, Beeching NJ, Bunn JE, Cooper C, Gardner $\mathrm{K}$, Iriyagolle $\mathrm{C}$, Hart CA. Hepatitis B prevalence and risk factors for HBsAg carriage amongst Somali households in Liverpool. Commun Dis Public Health. 2001:4:247-252.

14. Otkun M, Erdogan MS, Tatman-Otkun M, Akata F. Exposure time to hepatitis B virus and associated risk factors among children in Edirne, Turkey. Epidemiol Infect. 2005;133:509-516.

15. Ozdemir E. Significantly increased complication risks with mass circumcisions. Br J Urol 1997;80:136-139.

16. Ashraf $\mathrm{H}$, Alam NH, Rothermundt C, Brooks A, Bardhan P, Hossain L, Salam MA, Hassan MS, Beglinger C, Gyr N. Prevalence and risk factors of hepatitis $B$ and $C$ virus infections in an impoverished urban community in Dhaka, Bangladesh. BMC Infect Dis.2010;10:208.

17. Medhat A, Shehata M, Magder LS, Mikhail N, Abdel-Baki L, Nafeh M, Abdel-Hamid M, Strickland GT, Fix AD. Hepatitis c in a community in Upper Egypt: risk factors for infection. Am J Trop Med Hyg. 2002;66:633-638. 